\title{
Putting Indian Christianities into context: biographies of Christian conversion in a leprosy colony
}

\author{
Christian conversion in a leprosy colony
}

\author{
JAMES STAPLES \\ Brunel University, Uxbridge, Middlesex, UB8 3PH \\ Email: James.staples@brunel.ac.uk
}

\begin{abstract}
Gandhian and Hindutva-inspired discourses around conversions to Christianity in India over-simplify the historical nexus of relations between missionaries, converts and the colonial state. Challenging the view that conversions were ever only about material gain, this paper draws on long-term ethnographic fieldwork with leprosy-affected people in South India to consider the role that conversion has also played in establishing alternative, often positively construed, identities for those who came to live in leprosy colonies from the mid-twentieth century onwards. The paper draws out the distinctive values associated with a Christian identity in India, exploring local Christianities as sets of practices through which, for example, a positive sense of belonging might be established for those otherwise excluded, rather than being centred upon personal faith and theology per se. Biographical accounts are drawn upon to document and analyse some of the on-the-ground realities, and the different implications - depending on one's wider social positioning - of converting from Hinduism to Christianity in South India.
\end{abstract}

\section{Introduction}

A dominant strand of post-colonial thinking on Christian conversions in India and elsewhere posits that, historically, conversion occurred largely as an act of expediency on the part of the converted - for material and social gain - and/or in response to coercion from a powerful agent of conversion, usually backed by colonial authority. ${ }^{1}$ Such analyses mirror Gandhian discourses on conversion, which likewise critiqued proselytising that appealed to the stomach rather than to spiritual enlightenment ${ }^{2}$, and which equated conversion with a loss of Indian identity. ${ }^{3}$ It is the latter point that has been picked up upon and caricatured in recent years by the Hindu right, with Hindutva (Hindu-ness) promoted as an essential component of Indian identity, and Christian

\footnotetext{
${ }^{1}$ See, for examples, D. Kooiman, 'Conversion from slavery to plantation labour: Christian mission in South India (19 ${ }^{\text {th }}$ century)', Social Scientist 19:8-9, 1991, pp. 57-71; D. Hardiman, The coming of Devi: Adivasi assertion in western India. Oxford University Press, Delhi, 1987; V. Rafael, Contracting Colonialism: translation and Christian conversion in Tagalog society under early Spanish rule, Cornell University Press, London, 1988; R. L. Stirrat, Power and religiosity in a post-colonial setting: Sinhala Catholics in contemporary Sri Lanka, Cambridge University Press, Cambridge, 1992; P. Froerer, Religious division and social conflict: the emergence of Hindu nationalism in rural India, Social Science Press, New Delhi, 2007.

2 M. Thomas, Christian missions in the pluralistic context of India: the relevance of Gandhian approach, Unpublished PhD thesis, Mahatma Gandhi University, Kottayam, 2002; B. Kumarappa (ed.) Christian Missions: Their Place in India (by M. K. Gandhi), Navajivan Publishing House, Ahmedabad, 2000.

${ }^{3}$ There were, of course, counter discourses, including, most famously, Ambedkar's call to conversion - especially to Buddhism - as a route via which Dalits could escape the inequities of caste; a system which, in his view, was synonymous with the Hinduism Gandhi wanted to protect. See B. R. Ambedkar, Annihilation of Caste. Dalit Sahitya Academy, Bangalore, 1987.
} 
conversion synonymous with denationalisation. ${ }^{4}$ Contemporary positions against Christian conversion, now enshrined in laws in some States, also draw on similar arguments. ${ }^{5}$ In Tamil Nadu, Gujarat and Himachal Pradesh, for example, recent legislation has been passed that explicitly prohibits conversion by force or inducement, and which, in some cases, requires both missionaries and converts to notify local authorities before conversions take place. ${ }^{6}$

Material inducements, I argue in this paper, have some utility in explaining why people affected by leprosy, at least in the era dominated by institution-based treatment, might have became Christians. I will review some of the evidence for such arguments below. However, in focusing too much on these reductive and overly instrumental explanations of conversion - which both Gandhian and Hindutva discourses encourage - we also miss a great deal, and it is these gaps I want to focus on in this paper.

Firstly, there is a tendency in such accounts to over-simplify the relationship between leprosy-affected people and the missionaries who often cared for them, with missionaries caricatured as powerful agents of colonial authority and their converts as supine recipients of that power. A growing body of work sets out to nuance the relationship between mission and colonial subject. ${ }^{7}$ Secondly, more far-reaching explanations, spiritual and emotional as well as pragmatic, for rejecting Hinduism or Islam and embracing Christianity are left out of the picture. Motivations for conversion, as I shall demonstrate, are far from homogenous, and exceed the material. Thirdly, there is a danger that the variations in belief and practice that exist not only between different Christian denominations but also within a relatively small community categorized as a single faith, are elided. A closer ethnographic analysis of the lives of leprosy-affected Christian converts in the present - and the broader contexts within which their Christianity is practised - has the potential to speak to each of these concerns.

My aim in this paper, then, is to offer a more nuanced account of how Christianity is understood and practised in India by drawing on long-term ethnographic and biographical research with the inhabitants of a particular leprosy community in Andhra Pradesh, South India. Such accounts should not be read as alternatives but as complements to the wider macro-studies provided by, for example, Frykenberg ${ }^{8}$ and Neill. ${ }^{9}$ In order to do that, some general background on Bethany, the main site of the research on which this paper draws, is called for.

\section{A place called Bethany}

Bethany is a leprosy colony in coastal Guntur District, Andhra Pradesh: a selfestablished and run community of almost 1,000 people, separated by the main Chennai-

\footnotetext{
${ }^{4}$ C. Bauman, Christian identity and Dalit religion in Hindu India, 1868-1947, Eerdmans Publishing Limited, Michigan, 2008, p. 231.

${ }^{5}$ Ibid., p. 4.

${ }^{6}$ Ibid.

7 S. Dube, Stitches on Time: colonial textures and postcolonial tangles, Duke University Press, Durham and London, 2004; J. Comaroff and J. Comaroff, Of revelation and revolution, Christianity, colonialism, and consciousness, University of Chicago Press, Chicago, 1991.

${ }^{8}$ R. E. Frykenberg, Christianity in India: from beginnings to the present, Oxford University Press, Oxford, 2008.

${ }^{9}$ S. Neill, A History of Christianity in India 1707-1858. Cambridge University Press, Cambridge, 1985.
} 
Kolkata railway line from the compound of the mission hospital from which many of its settlers first came. Bethany takes it name from the village near Jerusalem identified in the New Testament (Matthew 26:6-13; Mark 14:3-9) as home to 'Simon the leper', and its inhabitants have, since its inception in the $1950 \mathrm{~s}$, identified themselves predominantly as Christians.

The earliest settlers had begun leaving the mission hospital in which many of them had lived, for up to a decade in some cases, in response to a change in hospital policy in the late 1950s. According to a doctor I interviewed who had once worked in the hospital, management had decided to put a stop to patients living and cooking for themselves in family units in order prevent injuries and offer more effective treatment. The drug Dapsone was also becoming widely available at around the same time, rendering leprosy curable and non-contagious, so there was also an impetus to release those who had been effectively treated. The subsequent emergence of Lamprene and, later still, Rifampicin - part of the Multi-Drug Therapy (MDT) currently used to treat leprosy - further accelerated the shift from what has become referred to as Institution Based Rehabilitation (IBR) to Community Based Rehabilitation (CBR). ${ }^{10}$

Although they were biomedically cured, however, many of those living in the hospital compound no longer had homes they felt able to return to. The majority of them had converted to Christianity while in the hospital, many of them marrying fellow converts who were not from their original caste groups. They were uncertain, as people affected by leprosy, of the welcome they might get if they returned to their natal places. Given the poverty from which many of them had come, returning home was often not a particularly alluring prospect in any case. Having become accustomed to living as families, however, neither were they prepared to return to living in ward conditions. Consequently, under the leadership of Prasad, who became the colony's first pastor, they left and began building themselves mud and thatch huts on the wasteland beyond the hospital compound. Free from the control of the hospital but also removed from its benefits most families sustained themselves by begging. ${ }^{11}$

Since then the village has grown from an initial 30 inhabitants to a population bordering on 1,000 people. Just below half the population has had leprosy; the rest is made up of the children and spouses of former patients. Around 150 people still go begging for the main source of their income, but several social development and welfare programmes - started by the foreigners who came to stay in the village from the early 1980s - now provide work for around 300 people. Between November 1999 and October 2000, the initial period of my fieldwork, there had been no resident foreigners in the village for five years, and development projects were managed by a project coordinator appointed from within Bethany. However, much of Bethany's income was still channelled through overseas donors and a management committee on which they, as well as villagers, were represented. This ensured a continued close relationship between Bethany villagers and 'the foreigner' - a shorthand category for their white, Christian patrons.

\footnotetext{
${ }^{10}$ P. K. Gopal, 'Introduction', in Guidelines for the Social and Economic Rehabilitation of People Affected by Leprosy, P. Nicholls, J. Nash and M. Tamplin (eds), International Federation of AntiLeprosy Associations, London, 1999, p. 3.

${ }^{11}$ For more background detail on begging, see J. Staples, 'Begging questions: leprosy and alms collection in Mumbai', in Livelihoods at the Margins: Surviving the City, J. Staples (ed.), Left Coast Press, Walnut Creek, CA, 2007.
} 
Settlers in the community came from a range of backgrounds: converts to Christianity from Hinduism, mostly, but also from the Moslem and Christian communities, who had found their way to the mission hospital via a number of different routes. Both they and their descendants now identified themselves, at least within the village, as Christians, most of them Lutherans. Nearly a third of the population came from the Mala or Madiga castes, Andhra's main scheduled (formerly untouchable) caste groups, many of whom were already Christians, and in some cases had been for several generations, before contracting leprosy. ${ }^{12}$ For the higher castes, however, conversions had usually occurred post-leprosy, either during treatment at the nearby mission hospital, or at another hospital prior to coming to the area.

There was no stated compulsion in the community's bylaws for members to practise Christianity. Membership was not overtly dependent on it, and there were - as we shall see - significant variations in how people practised. Nevertheless, it was the only publicly sanctioned religion, and was widely seen by villagers, especially the early settlers, as a feature that unified them as a community. In terms of everyday practices it was also difficult to avoid. The only place of worship in Bethany, for example, was and is a church, managed by an pastor, currently appointed from within the community, but affiliated with a local non-denominational Evangeline Fellowship. In addition to regular services - which attracted a congregation of up to 200 on Sundays and of between 20 and 50 for two evening services during the week - the church also hosted prayer meetings, well-attended youth groups and annual Christian meetings attended by local outsiders and visitors from other leprosy colonies. It was undoubtedly an important social space within the village. The broadcasting via a PA system of the Pastor's prayer sessions from around 4am each morning - as well as all other sermons and the congregation's participation in hymns - also ensured that the church's message was literally unmissable.

Private prayer meetings, officiated over by Bethany's pastor, outside pastors or other 'born again' Christian men within the village were also common, held by even the least devout to mark births, deaths and anniversaries, and all weddings and funerals in the village were Christian. Part of a local burial ground, shared with the mission hospital, was the only place available to bury the dead: there were no nearby Hindu cremation grounds, and Muslim burial grounds were set apart.

Public prayers were undertaken at the start of each shift in all the work departments officiated over by the Pastor or one of his assistants - and at the beginning of all meetings and before journeys. Daily rituals, in short, ensured that no-one could have been in any doubt over the community's religious identity, and reinforced who and what its members were to themselves as well as to outsiders. 'We are one caste, one disease, and one religion', in the words of one of the songs commonly sung in the church or during other prayers: a line often repeated in conversations I had with people when they wanted to stress their unity.

These shared Christian identities were also inscribed in the new generation and the newly converted by the bestowal of Biblical names as well as by changes in dress and decoration, particularly for women. Some of the most devout women, for example, ceased to wear jasmine in their hair; eschewed bindis or kumkum on their foreheads; and wore, if any, only the most simple of jewellery, usually including a cross. Cigarette smoking, consumption of alcohol, dancing and visits to the cinema were also strongly

12 Malas and Madigas made up 28.77 per cent of Bethany's population when I surveyed the community in 1999 , compared to 12.43 per cent of the municipality as a whole. 
frowned upon by those who identified themselves as 'true believers'. Bethany people shared, in Bourdieu's term, a distinctively Christian habitus. ${ }^{13}$

This habitus has not, however, been evenly embodied across Bethany's history. In the early days, for example, when Prasad, Bethany's founder, was the pastor, the church was seen as particularly strong. Although people's stories about those days were inevitably coloured by nostalgia, given that the community was much smaller and, because leprosy was literally inscribed on their bodies and their movements beyond the community boundaries were significantly more constrained, claims that the village used to be much more cohesive as a Christian community seem to me to be plausible. The church was always a power base within the village of one kind or another, however: one which overlapped with the power of the elected male Elders and, subsequently, fledgling associations such as the Youth Welfare Society (YWS) - for the second generation of Bethany men, without leprosy and therefore ineligible to join the Association - and the Mahila Mandal, or women's society. 'When the church was strong,' as one of my older informants put it, 'fewer people than today were prepared to smoke, drink alcohol and go to the cinema openly. They did all of these things, of course, but they did them secretly. Nowadays, with all the outside connections people have, the church doesn't have the same pull on them as it once did. Before, people didn't have anywhere else to go to worship, now, especially the younger generation, they can move around freely outside.' Change in village demographics - a growing population of people without leprosy, represented by the YWS - and wider external changes, which have led to what older members of the community see as a growth in individualism as opposed to the strong family values of the past, have clearly had an impact on how people practise religion within the village. Young men - and women, to a lesser extent - can chose to go to other churches, or to other places of worship altogether, if they are not satisfied with what Bethany's church has to offer.

\section{Pragmatics and conversion}

My initial assumption during fieldwork was that the people I worked with had become Christians both for the material benefits associated with it for people in their position, and/or because they felt compelled to convert in order to obtain the treatment and care they needed to survive. The medical treatment and care they had needed, for example, had only been widely available through mission hospitals, and the fact that residents' denominations largely reflected those of the institutions in which they had been treated, suggested that their conversions were directly related to their experience of those institutions. Subsequently, help had come predominantly from overseas, Christian (or assumed Christian) donors, reinforcing the material value of the connection. Donors were regularly thanked - and God asked to bless and help them - in public prayers by the Pastor or Elders at major meetings and events, and this served as a further reminder of the link between funding and what were perceived as their Christian patrons.

As described above, Christianity was also socially sanctioned and reproduced in the community where they now lived, and conformity to it eased their social participation. An openly Hindu woman I knew, for example - perhaps the only openly practising Hindu in the village - claimed that there were others like her who, on the basis of their religious beliefs, would chose to worship Hindu Gods, but, in an environment in which

\footnotetext{
${ }^{13}$ P. Bourdieu, The logic of Practice (translated by Richard Nice), Polity, Cambridge, 1990.
} 
evangelical Christians formed the majority, were not bold enough to do so openly. Although this may have been wishful thinking on her part, there is evidence elsewhere in the literature that other converts were motivated in similar ways.

The Satnampanth sect in central India described by Dube ${ }^{14}$ and, more recently, by Bauman $^{15}$, for example, had used conversion to Christianity to separate itself from a low caste (Chamar) identity in the late nineteenth century. A major draw in their case was the prospect of a materially better life within the paternalistic economy of the mission station, along with the availability of efficacious missionary medicine, jobs, training and low interest loans. ${ }^{16}$ When eligibility for government aid later became contingent on identification as low caste Hindus, however, they were able to shift back across the religious divide, suggesting that, for them, religious conviction was less significant than material opportunity. Likewise, in famine ridden Ongole $-100 \mathrm{~km}$ south of Bethany - conversions to Christianity in the same time period were restricted initially to the lowest caste groups, with others only coming forward as the famine persisted and the economic and spiritual benefits of conversion became more alluring. ${ }^{17}$ Manor also records that when, in 1930, around 15 families of Kammas (a land-owning, farming caste) in one community became Christians, 'they are said to have acted out of a desire for agricultural assistance from missionaries'. ${ }^{18}$ Hindus entering missionary leprosy hospitals nearly a century later might likewise have been attracted to what was on offer.

As has also been noted, however, material gain alone was not in itself sufficient to explain all conversions. Indeed, converts during the colonial era were often viewed with hostility and suspicion by European officials and were less likely to be offered administrative jobs than their Hindu peers. They also became 'non-beings', losing both status and property in their former communities, ${ }^{19}$ suggesting that not all the benefits were on one side, and that in some cases they might also have been out-balanced by material disadvantages. The same might well be applied to the era of Hindutva, at its peak when I undertook the bulk of my research at the turn of the twenty-first century, with conversion not only excluding the lowest castes from the reservations for jobs and college places they might otherwise have had access to, but also leaving them open to accusations of un-Indianness. ${ }^{20}$ Such issues were very much alive in Bethany during my 1999-2000 fieldwork, when church bombings in the region had left them feeling vulnerable to outside attack. ${ }^{21}$

\footnotetext{
${ }^{14}$ S. Dube, Untouchable pasts: religion, identity and power among a central Indian community, State University of New York Press, Albany, 1998.

${ }^{15}$ Bauman, Christian identity and Dalit religion in Hindu India.

${ }^{16}$ S. Dube, 'Paternalism and freedom: the evangelical encounter in colonial Chhattisgarh, Central India'. Modern Asian Studies vol. 29, no. 1, 1995, p, 177.

${ }^{17}$ E. Rauschenbusch-Clough. While Wearing Sandals or Tales of a Telugu Pariah Tribe. Hodder and Stoughton, London, 1899. See also A. Copley, Religions in Conflict: Ideology, Cultural Contact and Conversion in Late-Colonial India, Oxford University Press, Delhi, 1997, p. 53.

${ }^{18}$ J. G. Manor, 'Testing the barrier between Caste and Outcaste: The Andhra Evangelical Lutheran Church in Guntur District, 1920-1949.' Indian Church Review 5, 1971, p.30.

${ }^{19}$ Copley, op. cit., p. 54.

${ }^{20}$ Bauman, op. cit.

21 For specific examples of Christians being targeted by the Hindu right wing see S. Sarkar, Conversions and the politics of the Hindu Right. Economic and Political Weekly, 26 June 1999, vol. 26, pp. 1691-1700.
} 
When people converted in spite of the social and, sometimes, economic costs, Forrester $^{22}$ argues, there was also evidence of a genuine desire among converts for spiritual improvement, particularly for low caste Hindus who were anyway often excluded from mainstream religious practice. As Christians, pastors regularly told them, they could be redeemed. 'There is no bad karma when you come to Jesus Christ,' in the words of a major overseas Christian donor who addressed a local congregation during my fieldwork. 'It doesn't matter who you are or even what you've done in this life. When you come to Christ, your sins, what you've done, are wiped out and forgiven.' Although those I worked with made very little mention of an afterlife or of reincarnation - karma, when it was invoked at all, was usually little more than a rhetorical explanatory device, without reference to rebirths - this promise of a clean slate was nevertheless appealing to those affected by leprosy, whose identities otherwise remained negatively defined.

Christianity generated, for low castes and for those excluded by virtue of a disease identity like leprosy, 'self-respect and a world view which is consistent with and justifies an everyday renegotiation of subordination'. ${ }^{23}$ The Satnami converts Dube refers to likewise associated conversion with a change in social status. Dube cites one man who, asked to perform a menial task, is quoted in the archives as responding: 'No, I have became a Christian and am one of the Sahibs; I shall do no more begar' ${ }^{24}$ As I have argued elsewhere ${ }^{25}$, leprosy-affected people in contemporary India were also able to negotiate new, more positive identities through Christianity, where their condition was not seen as a consequence of negative karma, but, in some instances, as the route through which they had found God. As Christians, meat-eating, for example, became seen as a positive celebration of their identity, rather than as a habit that demarcated inferiority or pollution ${ }^{26}$. Conversion allowed other boundaries also to be redrawn. Indeed, a Christian worldview allowed Hindus who might otherwise be situated as their superiors to be re-imagined as figures of ridicule, less sophisticated than themselves and from whom respect should be forthcoming. 'They think everything is God!' laughed one converted Madiga woman I knew. 'A tree, a snake, everything!' Such mockery could, of course, also occur within Hinduism. A favourite story of a Shudra caste male friend of mine was about how, as a child, he had enjoyed polluting Brahmins by jumping out at them as they returned from temple, requiring them to re-undertake the time-consuming task of their purifactory pujas. Although he did not overtly buy into the Brahmin view that he was ritually inferior to them, however, he recognized his position within a hierarchical system, and the form of his critique relied on him staying in that position. Christian converts, by contrast, saw themselves as outside of such a system

${ }^{22}$ D. B. Forrester, Caste and Christianity: Attitudes and Politics of Anglo-Saxon Protestant Missions in India. Curzon Press, London, 1980.

${ }^{23}$ D. Mosse, 'Responding to Subordination: The Politics of Identity Change Among South Indian Untouchable Castes', in Identity and Affect: Experiences of Identity in a Globalising World, J. R. Campbell and A. Rew (eds), Pluto Press, London, 1999, p. 76; see also C. Busby, 'Concepts of religious power in a fishing village in South India,' in The Anthropology of Christianity, F. Cannell (ed.), Duke University Press, Durham, NC, 2006, pp. 77-98; and J. C. B. Webster, 'The Dalit situation in India today', International Journal of Frontier Missions, vol. 18, no. 1, 2001, pp. 15-17.

${ }^{24}$ Dube, 'Paternalism and freedom: the evangelical encounter in colonial Chhattisgarh, Central India', p. 181, citing C. P. Ethnographic Survey XV11, draft articles on Hindustani Castes, $1^{\text {st }}$ series, Nagpur 1914, p. 57.

${ }^{25}$ J. Staples, “ "Go on, just try some!" Meat and meaning-making among South Indian Christians'. South Asia: Journal of South Asian Studies, vol. 31, no. 1, 2008, pp. 36-55.

${ }^{26}$ Ibid. 
and, therefore, able to position themselves as potentially superior to it. Christianity was, as Busby ${ }^{27}$ argues, an oppositional discourse of identity: one that might be stuck with despite material costs rather than because of financial gains.

In short, then, conversion was not just about material benefit, even though it was intricately linked to the particular political and economic circumstances within which it took place. For the leprosy affected people I worked with, certainly, it was also about meeting perceived spiritual and emotional needs, and about membership of a wider social group with a more positive identity than that afforded by leprosy alone. By moving further into the biographies of Christians who live in Bethany - and the interconnections between them - I will elaborate further on what being a Christian meant in practice below. First, however, I want to explore a little further the relationship between the missionary and those they set out to convert.

\section{Missionaries}

As van der Veer points out, post-Kantian portrayals of Christianity have aligned the religion to Western projects of modernity, with Hinduism, by contrast, 'mystified as Oriental wisdom or irrationality'. ${ }^{28}$ Although the colonial state was seen by the indigenous population as Christian - despite protestations that it was religiously neutral - the binary oppositions of Christianity/Western/Colonial on one side and Hindu/Eastern/anti-colonial on the other, overdraws the distinctions between the two. And while inequalities in power between the two poles certainly mitigated against open dialogue ${ }^{29}$, the image of a purely indigenous society responding to the entirely external force of the colonial state would be overly reductionist.

For one thing, missionaries were not simply a sub-set of the colonial ruling class, with the contradictions between the aims of 'civilising mission' and 'religious neutrality' often putting them directly at odds with one another. ${ }^{30}$ Missionary critique of colonial abuses in India, as Woodberry ${ }^{31}$ points out, led to a fracturing of British dominance and - even though missionaries did not position themselves as anti-colonial - provided the initial motivation and the organisational structures from which the independence movement gained momentum. ${ }^{22}$ Indeed, an alternative classification might be to group together missionaries and their lower caste converts - who broadly applauded missionary work to outlaw slavery, uriyam (forced labour) and various forms of caste discrimination ${ }^{33}$ - and oppose them to an uneasy alliance of Hindu elites and

\footnotetext{
${ }^{27}$ Busby, op. cit., p. 96.

${ }^{28}$ P. van der Veer, 'Religions in South Asia.' Annual Review of Anthropology, vol. 31, 2002, pp. $175-$ 176.

${ }^{29}$ Ibid., p. 197.

${ }^{30}$ K. Kawashima, Missionaries and a Hindu State: Travancore 1858-1936. Oxford University Press, New Delhi, 1998, p. 80.

${ }^{31}$ R. Woodberry, The shadow of empire: Christian missions, colonial power and democracy in postcolonial societies. PhD thesis, University of North Carolina at Chapel Hill, 2004, p. 76.

32 Ibid., p. 117.

${ }^{33}$ K. Kawashima, op. cit., p. 38; G. Oddie, 'Protestant Missions, Caste and Social Change in India, 1850-1914.' The Indian Economic and Social History Review, vol. 6, no. 3, 1969, pp. 259-91; G. Oddie, 'Christianity and Social Mobility in South India 1840-1920: A Continuing Debate.' South Asia, vol. 19 (special issue), 1996, pp. 143-59; G. Oddie, Missionaries, Rebellion and ProtoNationalism. Curzon Press, Richmond, England, 1999.
} 
the colonial authorities, for whom religious conversion was often problematic. ${ }^{34}$ Even this, however, would be too oppositional. Rather, missionaries might better be seen as occupying 'a unique bridging position between the colonized and the colonizing state'. ${ }^{35}$ Christianity in nineteenth century India developed and was shaped within the three-pronged encounters between the indigenous population, missionaries and the colonial state.

Even when the objectives of the state and missionaries overlapped, there was no guarantee that their actions in relation to the indigenous population had the intended effects. As the Comaroffs put it in relation to mission in colonial southern Africa, for converts, '...even as they are encompassed by the European capitalist system... these "natives" of other worlds often seek to seize its symbols, to question their authority and integrity, and to reconstruct them in their own image'. ${ }^{36}$ It was, then, in the 'tensions of Empire ${ }^{37}$ that colonial subjects found the tools with which to resist it. Dube's Satnami converts of the late nineteenth century, for example, utilized the awareness of inequality inculcated in them by missionaries to question the practices of those same missionary authorities. $^{38}$

There were certainly comparable ambiguities inherent in the relationship between people affected by leprosy and the missionaries who cared for them from the late nineteenth century onwards. For a start, it was not only that leprosy affected people were offered opportunities by the missionaries; they were also seen as opportunities in themselves, and this re-balanced the power relationship somewhat. 'It has been proved over and again that lepers in a class lend a ready ear to the gospel, and many spirituallycleansed lepers are to be found throughout India', Wellesley Bailey ${ }^{39}$, founder of the Mission to Lepers in 1874, argues, while Cochrane, a consultant leprologist for the same mission, half a century or so later, realizes that:

... in the new leprosy outlook a great field for missionary endeavour has been opened up, for through the early leper people and lands could be reached. The evangelisation of the world depends on the indigenous people of each nation, and what better missionary could be found than the leper cured of his disease, going back to his people telling them out of the fullness of his heart, the two-fold gospel of spiritual and physical healing. ${ }^{40}$

Not only did missionaries depend on the willing as much as the converts depended on them, but converts also, in some cases, challenged missionary authority - and that of the colonial state more generally - by using the language of evangelical Christianity. ${ }^{41}$ This is mirrored in the actions of contemporary leprosy patients as they make their case for access to ever diminishing resources for their care. For example, Bethany villagers

\footnotetext{
${ }^{34}$ G. Viswanathan, 1998. Outside the Fold: Conversion, Modernity, and Belief, Princeton University Press, Princeton, New Jersey, 1998.

${ }^{35}$ Woodberry, op. cit., p. 80.

${ }^{36}$ Comaroff and Comaroff, op. cit., p. xi.

${ }^{37}$ John Comaroff, 'Images of Empire, contests of conscience: models of colonial domination in South Africa.' American Ethnologist, vol. 16, no. 4, 1989, p. 662.

${ }^{38}$ S. Dube, Stitches on Time: colonial textures and postcolonial tangles, p. 43.

${ }^{39}$ W. C. Bailey, The Lepers of Our Indian Empire: A Visit To Them In 1890-91, John F. Shaw \& Co., London, n.d., p. 224.

${ }^{40}$ R. G. Cochrane, Leprosy in India: A Survey, World Dominion Press, London, 1927, p. 22.

${ }^{41}$ Dube, 'Paternalism and freedom: the evangelical encounter in colonial Chhattisgarh, Central India', p. 201.
} 
wrote and produced a play, at my request, to tell their version of their community's history. In the play, Christian duty, while valorized, was also deployed as a weapon against those - Christian missionaries and donors among them - who might reject supporting those affected by leprosy. In a line clearly aimed at the envisaged audience of donors viewing a video of the play back in Europe - caricatured in village discourse, and in the play, as rich, white and Christian - the actor playing the project co-ordinator looked directly into the camera and warned: "If we think, "Why should we give more money for these leprosy patients?", if we think like that, we'll get cursed by God.'

The missionaries in the hospital who discharged them - by then, a post-colonial mixture of indigenous medical professionals and nurses stationed there from the UK were likewise criticized in the play for their unchristian behaviour in 'throwing us out like dogs'. So while Christianity is mostly used in this sense as a qualification for making claims - 'we are Christian so you must help us!' - it also enabled judgement to be made, and pressure to be exerted upon, those thought to share the same values.

\section{Differentiating between Bethany's Christians}

There are a number of ways in which Bethany's Christians - the vast majority of them identifying as Protestants - might be differentiated. There is, for example, a clear relationship between caste and religion, as I have explored in detail elsewhere, ${ }^{42}$ with the lowest castes more likely to have converted prior to having contracted leprosy and demonstrating the greatest commitment to Christianity and, unsurprisingly, the strongest resistance to being identified by caste. 'I was a Mala but now I'm a Christian', as people often expressed it, suggesting that, for people from scheduled castes, Christianity offered a more positive identity. By my estimation, somewhere between 15-30 per cent of Bethany's original settlers had been Christians prior to contracting leprosy, and so their conversions - or those of their ancestors - were not directly linked to their experience of the disease.

Things were seen differently by members of other castes, for whom Christianity was not an escape from low caste status but, in some cases, synonymous with it. 'I was a Rajulu [Kshatriya] but now I'm a Mala,' commented one of the more devout Christians from a high caste: he had not lost a caste identity through conversion but had gained a new one. For the less devout, however, high caste status was hung on to - even when they married outside it - and while such converts adhered to Christian practices in the village, they were more likely to revert temporarily to Hinduism when visiting their natal homes.

Gender and age also differentiated Christians within the village, with women and older converts generally being more devout than men and the younger generation reared in the community. The fact of leprosy itself might also be explored as an important distinction between Bethany's Christians and those of the broader locality. The most significant distinction, however, regularly drawn by the villagers themselves, was between what were termed 'true believers' and everyone else - what I call here, for want of a better term, 'regular Christians'. ${ }^{43}$ It's a distinction that has also been noted elsewhere; in the work of Oddie, for example, who claims that while for many people

\footnotetext{
${ }^{42}$ J. Staples, Peculiar People, Amazing Lives: leprosy, social exclusion and community-making in South India, Orient Longman, Delhi, 2007, pp. 151-153.

${ }^{43}$ I have opted for this term rather than for 'nominal Christians' because even the least devout of Bethany's Christians tended to identify themselves as Christian in more than just name.
} 
conversion meant little more than a change of community, for others it also signified a major change in the way they lived and to their 'inner lives', or marked the beginning of a slow process of change. ${ }^{44}$

The 'true believers', in Bethany, were largely comprised either of those who were already Christians before contracting leprosy - mostly from Mala and Madiga backgrounds - or were 'born again' converts. The latter group was made up mostly, but not exclusively, of second generation Bethany dwellers: the sons (usually) of leprosy affected people who were nominally Christian, by virtue of their birth in a Christian community, but who had undergone at least one, and in some cases several, religious transformations. They were often people who might previously have been classified as 'regular Christians' simply by virtue of their residence and upbringing in the colony, but who had not necessarily been baptised, and whose religious practices impinged only marginally on their day-to-day lives.

Variations within membership of both of these groups suggests more of a continuum between 'true believers' and 'regular Christians' rather than bounded categories particularly as there was significant movement at the boundaries between them - but there were nevertheless a number of characteristics that distinguished 'true believers' to their fellow villagers. Firstly, they were all baptised, and they were more likely than other villagers to use their Christian names. They talked openly and regularly of God ('Praise the Lord!', 'God is great!' or 'Hallelujah!' were common appendages to sentences); they prayed openly and out loud; and they would often reprimand or criticize others for such activities as smoking, visiting the cinema or drinking alcohol (even though some of them occasionally indulged in some of these activities). Religious identity was embodied, and reconstituted through acts drawn from a repertoire of what were considered locally as Christian actions.

Christianity for them was not private or about internalized, individual belief - or at least it was not only about that - but was constituted through very public practices and utterances, and through dress and presentation. When my cook, Estheramma - a devout Baptist - felt that one of the colony's project administrators was questioning her honesty by probing her about the price she had paid for fish, for example, she drew on her Christian identity to express her outrage. Clearly offended and fighting back tears, she told me: 'I'm a Christian! A regular churchgoer! How dare they suggest that I'm eating the money. We true Christians don't behave in that way!' Not only did she use her Christian identity as evidence that she would not steal - a form of social capital but she also differentiated herself from the colony employee and others like him who, although ostensibly Christians, were, in her opinion, only nominally so. 'All he does is drink liquor all day long!' she railed. 'Look how he conducts himself! He is not a prayerful man.'

Many of the 'true believers' group had also developed strong networks with pastors and congregations beyond the village, built up through family connections in other communities - particularly common among those who came from originally Christian backgrounds - and from big local prayer meetings. Such connections were to some extent institutionalized: the Elders, for example, would regularly seek marriage partners for Bethany residents from other Christian leprosy colonies, the links between which were initially established via Pastors within these communities. At a family level, however, the 'true believers' often sought more direct connections. Links with

\footnotetext{
${ }^{44}$ G. Oddie, Hindu and Christian in South-East India, Curzon Press, London, 1991, p. 141.
} 
American evangelists were particularly sought after, for example, because they could lead - as they had done in one or two cases - to opportunities for their children to travel to theological colleges overseas, or for funding that would allow them to set up their own organisations. Estheramma, for instance - whose family had been Christian since the conversion of her grandfather, before the birth of her own father - had used connections with pastors in other colonies to arrange the marriages of both her daughters, and one of them had a secure job with a mission organisation. Another lowcaste Christian woman I knew, Mariamma - who had once worked in Bethany and now lived in the neighbouring town - had managed to forge ongoing links with a church group in Texas, which now funded her orphanage of around 40 children. This had significantly enhanced Mariamma's standing, and that of her family, within the locality. She was, by virtue of her connections, able to play the role of patron. Although such successes as Mariamma's were relatively uncommon, they served, as frequent references to her case illustrated, as examples to others of what could be achieved materially and socially - through a deep Christian commitment.

This more senior contingent of 'true believers' of which Estheramma was a part, many of them women from Christian backgrounds, attended the evening church services as well as those on Sundays, and most of them would also fast twice during the week prior to the evening services. Younger believers, however, had sometimes broken off, unofficially, from Bethany's church, claiming that the current pastor was not evangelical enough. They had instead aligned themselves with outside churches. Under the leadership of external pastors, they attended and sometimes officiated over prayer meetings, and helped out with services for newly converted congregations in nearby tribal communities. These men were also called on within the village when the pastor was unavailable to conduct prayer meetings to mark, for example, anniversaries of parents' deaths or the first birthdays of children.

In this sense, while the men's actions might be taken as evidence of their religious commitment, they were - like Mariamma's orphanage - also clearly seen as a particular way to get on in the world. Financial gains may have been small, but a reputation as prayerful and able to conduct Christian life cycle rituals also gained them respect among fellow villagers and among Christian outsiders, and - as several of them expressed it to me - a kind of self-respect that they had not always had previously. As most of these young men came from low castes, these activities also shifted the focus from caste or disease-based identity to religious status, with the latter seen as considerably more positive. 'When I go with pastors to other churches outside,' as 25-year-old Yesuratnam explained to me, 'the people there see me first as a Christian - as one of them - rather than as part of a leprosy colony. And if we also demonstrate a good knowledge of the Bible and can use examples nicely to explain to people what Bible stories mean, they will also respect us for that.'

Regular Christians in the village, by contrast, tended to take a more flexible approach to their religious identity, sometimes reverting to Hinduism or Islam during visits to their native places. 'Here it's a Christian village, so that's automatically the religion I follow,' as one man explained it to me. 'In my native place, automatically I'm a Hindu.' For him, as he elaborated, religious practice in general was more important than the form that practice took. Many of this type of Christian were also baptised, even though this had often been simply a precursor to a Christian wedding. It was just 'part of the necessary procedure' as another man described it when I pressed him. 'There was no other choice,' he told me, 'In this colony, if we decide to come and live here, these are 
the customs we follow. If I'd married in my uncle's house, it would have been a Hindu ceremony. But we aren't thinking deeply about these things: we just want to get married, that's all!'

At the same time, they were also more likely to continue with traditions that, from the 'true believer's' perspective, were seen as unchristian. David Babu, for example, was the son of parents who had converted after contracting leprosy, and who had been brought up within the community. When it came to buying a new water pump for some farm land the family was renting, however, he consulted not the pastor but Gopal Krishna, a man renowned for his understanding of the Hindu calendar. Before making his purchase, he said, he wanted to know which day in the next week would be the most auspicious. 'I am a Christian for sure,' he told me when I asked him about it, 'but these are our customs, no? And anyway, if we check the calendar and pray as well it's even more likely that we'll buy the pump at the correct time!'

Fatima, the Muslim wife of a Madiga converted Christian, demonstrated a comparable syncretism and flexibility concerning religion, exemplified by the fact she had a large cross painted on one side of her front door, and an equally prominent crescent moon and star on the other. Her children each had three names: the Muslim names she had given them and which were used by her extended family; Christian names given to them by the pastor when he baptised them; and the Hindu names under which they were recorded in Government records, allowing them to access any State benefits that might accrue from their father's scheduled caste status. She was also happy for the children to attend Sunday school, church and prayer meetings - the latter of which she also attended - although when it came to finding a marriage partner for her daughter, she was insistent that the match should come from the Muslim community outside the village. In part, this was about reintegrating the next generation of her family back into the extended network of relations from which she had come and, to some extent, had excluded her. For her, being a Muslim was about more than just religious belief. However, she also felt that for herself, as a woman severely physically impaired by leprosy, membership of a Christian leprosy community - and the kind of care associated with Christianity - offered the best chance available of a better life. She was a pragmatist, to be sure, but her nominal adherence to Christianity was not simply a matter of material gain.

'Regular Christians', like those I have described above, were also less likely to use Christian names except in particular circumstances where they might have been useful, and, when they attended church at all, only went along on Sundays. Others stayed away apart from major prayer meetings - which were also feast occasions, so there were other reasons for attending them than the purely spiritual - and prayer meetings to mark anniversaries, which were expected and unavoidable. Although there was no absolute correlation between caste background and religion, Madigas and Malas were far more likely to classify themselves - or be classified as - 'true believers' than those from caste Hindu backgrounds. Muslims were also much more likely than their Hindu counterparts to continue describing themselves as Muslims, even after formal conversion.

\section{A tale of two Christians}

Christianity, then, took particular forms within the village depending on who you were and how you stood in relation to others within the community. While I hope to have captured above some of the general threads of how people distinguished themselves in 
relation to one another and outsiders, I want to offer now two very different biographical accounts of Bethany men, both Christians, as the embodiments of the some of the distinctions I have been describing.

The first is Krishna, a Brahmin man. Born into a very high caste, but materially poor family in rural Tamil Nadu, his family practised Hinduism, 'just not very deeply', as he put it. 'We went to temple and other things: my mother would go every Friday... and we'd attend at festival and special puja times, but there are some people who will go everyday.' After they moved away to a nearby town, the pressure to worship diminished, particularly as his father - hounded by the debts of failed businesses regularly absconded and was absent for several years at a time, leaving Krishna to his own devices.

By the time Krishna discovered he had leprosy he was 19 and already living away from home, working in a job one of his maternal uncles had found for him, as a store keeper in a small factory in Bombay. He left the job as soon as he had been diagnosed, believing, as he put it, that his life was over, and that his colleagues would not accept him once they knew. The next ten years or so were spent living on the roadside and working informally as a porter and hotel tout on railway stations, first in Bombay and, later on, back in Madras.

There was not much opportunity for religious practice in either of these locations. 'Before going to work in the mornings, we'd just wake up, move a hand around our faces, lower our eyes, ask God to help us... like a silent prayer. Then life would go on, we wouldn't think deeply about it.' He did, however, celebrate a range of festivals with his fellow station dwellers, who included among them a Goan Christian who supplemented his income by selling arrack, Hindus and Muslims. He ate and associated freely with people from across religious communities and caste divisions, but he did not drink alcohol and, true to his identification as a Brahmin, he never ate meat.

When he was reunited with his father in 1981 - who, it transpired, had also left home with leprosy at around the same time as Krishna did - the older man was already living in Bethany, having arrived there by way of several mission hospitals. The Catholic Church ran the first of them, where he had met and married his second wife, and this remained their official denomination. Krishna resisted his father's initial requests for him to go and live with them in Bethany, although eventually relented a few years later, when he agreed to a marriage his father and step-mother had arranged for him. His bride, Grace, was from a much lower caste than he was, but was also the daughter of leprosy-affected people from a Christian community. 'They had been Hindus but had followed Christianity,' he said, 'they were not baptised, but they went to church sometimes.' Grace and Krishna, however, were baptised directly before their wedding, which took place along with three other couples during annual prayer meetings in a nearby village. Krishna, who did not at the time speak the local language, had only a vague idea at what was going on, although he knew his father and step-mother were Christian converts, so was not surprised or disturbed by the fact that the ceremony was a Christian one.

Initially, Krishna attended the church in Bethany with his father on Sundays, although as his Telugu improved he found himself increasingly at odds with the pastors' messages. 'Most of these lay Evangeline fellowship preachers just curse you or blame you rather than preach,' he said. 'They don't tell about the God, just that if you do this or that, if you are a smoker, go to the cinema, you will die, you will perish. I didn't like that approach. Nor should they tell us that if we are praying to this God or that God we 
will perish or die. If that's the case, how are Hindu people surviving, becoming popular and wealthy? They pray only to those Gods, but they don't perish!' Nowadays he attends church with his family only at festival times and for weddings and, although he describes himself as a Christian, it is subordinated to, although not necessarily incompatible with, his identity as a Brahmin, which he is much quicker to reveal to people he meets than his religion. Like, in his view, the majority of villagers, he also slips back easily into his identity as a Hindu when he visits other family members outside the community.

Samson, by contrast, was born in Bethany and, like many of his generation, does not have an alternative religious identity to slip back into. His father, Devasahayam, and mother, Estheramma, had met, married, and converted to Christianity in the nearby leprosy mission hospital. By caste, Devasahayam was a barber and a musician, supplementing his income from begging by cutting people's hair and, later on, giving music lessons in the school. He also provided music in church and during prayer meetings, and organized the musical arrangements for village drama performances, which usually had an explicitly Christian content ${ }^{45}$. Both he and has wife would have classified themselves as true believers. Samson, however, had a more chequered religious history, which he summarized in what was fairly typical testimony given by born-again Christians at Bethany prayer meetings. During prayer meetings in 2000 he took to the stage and told the gathered congregation:

... I used to steal, chase girls, drink alcohol, get involved in fights and land in trouble with the police... I went for welder's training... but I didn't attend properly, wasted much of my time. There was a Pastor there who observed me. He came to my side and he said, 'Please, believe in God, in Jesus, then He will forgive your sins.' I didn't take much notice, but he kept coming, again and again, pressing me, telling me, 'God loves you!' After a year of him pressing, over and over again, I finally agreed - just to get some peace from him - to go to church. The Pastor believed that I had changed, but I hadn't - I was still chasing girls, still drinking and smoking. The Pastor asked me to take baptism and I agreed, but I went for my baptism with my cigarettes still in my shirt pocket and after I had been for a drink! Then the Pastor sent me to spread the message, and I went to meetings in five different States, but I still hadn't changed. I was still making the same mistakes.

Then, six years back, I went to [local prayer meetings], and one pastor who was talking to me said: 'You're sitting here, you're praying and singing, but your heart is somewhere else.' Later the Pastor told everyone to disperse, to go and pray on our own, and I thought, this is a good opportunity to go and look at the girls. But when I got to the corner I watched a small boy crying, and I thought, I'm here, I had may as well pray. So I sat down and started praying, and then I got touched by God. I cried loudly, continuously for 12 hours, and after sometime I heard a voice: 'You are my son. I am warning you.' It was very loud. I looked round to see if I could see anyone but there was nobody there. I was afraid. Again I started praying. Then the voice gave me a Bible reference. I didn't have a Bible with me so I went back to my house and looked up the reference. There were the words: 'You are my son. I am warning you.' Again I prayed, and I went to the pastor and told him how I'd cheated him in the past.

\footnotetext{
${ }^{45}$ On one occasion, I recall, he was asked by the office to tone down one of the school drama productions he had helped to produce, in which the children talked gleefully of Hindus being struck down by God and thrown into the eternal fires or damnation.
} 
But after about six months, I got into problems again. I worked at the airforce camp as a welder, and I was popular among my fellow workers. And the other officers would press me: 'Come on, it's my birthday, come and have a drink.' And gradually I returned to my old life.

But then problems came in my family. My brother died of AIDS. My mother lost her eye. And I thought, this is my fault, these things have happened because of my mistakes. So I repented, and I fasted for three days. I left that job and set up my own business, and if my old friends come from that life and call me I say no, that I've left that life, but if they want to sit with me in the shop, listen to Christian songs or to ask me questions about the Bible, then they can share my friendship. From now until my death, I will try to make no more mistakes. ${ }^{46}$

Samson's testimonial was fairly typical of those popular at mass prayer meetings: his colourful tales of debauchery, while frowned upon, were entertaining, and could be listened to in the knowledge that he had now repented, shifting across the boundary from being a 'regular Christian' - which he was otherwise - to becoming a 'true believer.' Such stories are not only indicative of the movements people made between the states of regular and true Christian belief, but were also important in showing people that such movement was possible. If prayer meetings resulted in more attendees formally converting through Baptisms, then they were seen as a success.

The last time I saw Samson, eight years after the above testimonial, he appeared to have lapsed once again: although he yelled out 'Praise out the Lord!' to me as we passed in the street, the facts that his eyes were blood shot, that he could hardly stand up and that he was beaming from ear to ear, suggested he was drinking again. 'I thought he was a reformed character,' I remarked to my research assistant, who was walking along with me. 'Ah yes, Samson is always reforming,' he replied.

\section{Discussion}

Although Samson was an extreme example, his stylised accounts of the criss-crossing of Christian boundaries within the community do index a more common pattern among, in particular, young village men, who negotiate between the demands of family and community on the one hand, and the attractions and influences of a much wider world than that which was open to their parents on the other. Krishna's rather downbeat performance of Christianity was also, in its way, an extreme example, both because of his capacity for self-reflexivity - perhaps induced by the fact that he had just spent several days recounting his life history to me - and for his critique of pastors' messages, but it was also an indication of the variations in Christian beliefs and practices that existed within Bethany. What both narratives show, is that local Christianities, while still bounded and distinguishable from other religions, are also extremely flexible, particularly in the face of competing demands placed on their practitioners.

What both cases also point to are the various ways in which Christianities might be variable within the village beyond the most commonly made distinction between true believers and the rest. Samson, for example, appeared to move - at least according to his rhetoric - between two Christian identities, but, unlike Krishna and others I have described, for him there was no recourse to Hinduism or Islam. Those who were born and brought up in Bethany had far fewer Hindu or Moslem reference points than their mothers and fathers before them, who - although they had converted - still embodied

\footnotetext{
${ }^{46}$ Reproduced from Staples 2007, op. cit., p. 164-165.
} 
certain movements and dispositions that might be associated with Hinduism. Some of those from the older generations also retained greater links with non-Christian networks outside the village - such as the Moslem community with which Fatima still identified and could still draw on these connections if the need demanded. True believers or not, however, for most of Bethany's younger generations there was no recourse to other religions: established networks were with the youth of other leprosy colonies.

The older generation, then, looked back to Hindu or Moslem pasts and, for the most part, envisaged Christian futures within the confines of the leprosy colony. For those born in Bethany, however, and especially men, there was a range of cross-cutting options. Unlike their parents, they were not disfigured by leprosy, and so could - and, increasingly, were compelled to - look outside the village in imagining their futures. Samson, for example, was not eligible to engage in colony politics through standing for election as an Elder because, as someone without leprosy, he was not eligible to join the association of which his father had been a part. Discouraged from his parents from begging, a choice anyway impaired by his lack of leprosy deformities, and unlikely to be offered one of the jobs created for leprosy-affected men and women within the colony, he and his peers increasingly had to look beyond the village for work. In his case, this had meant a job at the local airforce base - a location where, according to his account, he had succumbed to alcohol and women. For others, unless they found opportunities as preachers or - as several did - with other Christian NGOs, outside working likewise exposed them to influences from which their parents' generation were to a larger extent sheltered. It did not mean that they re-converted back to Hinduism, but it did mean they had to learn to operate in more secular environments than those who remained within the village.

At the same time, without political influence within Bethany, Samson's generation also looked to other sources of power than the Elders or the colony's church in order to make their mark. The Youth Welfare Society (YWS), for example, was specifically engaged in raising funds for the younger, healthy generation to construct houses, and did so by forging links with local political parties and other organisations.

Again, this is not to suggest that Bethany's younger generations were abandoning Christianity in favour of whatever religion their new patrons might support - and, indeed, many of their claims drew precisely on their identification as Christian - but it did potentially make for a re-envisaging of their Christian practices in ways that worked best for them.

\section{Conclusion}

In summary, then, what I have tried to show is that local Christianities are best understood in relation to the local contexts with which they intersect rather than solely against the colonial backdrop against which many of them emerged. Such local contexts include politics, economics, social expectations and spiritual needs, as well as gender and age categories.

As has become clear, where one was positioned along the continuum between 'true believer' and 'regular Christian' - an axis which, within Bethany at least, seemed to cross-cut denominational distinctions - was an assertion of more than one's religious affiliations. In the context of a leprosy colony, it also spoke to the relationship between religion, caste and disease status, and how people negotiated their identities in relation to them. In most cases, those of relatively high caste status were keen, despite their 
conversions to Christianity, to retain distinctions between themselves and those of lower status, even if openly articulating such distinctions were frowned upon. While, on the face of it, conversions were publicly claimed to elide caste and other differences, in reality there was space along the continuum I have described to negotiate an identity by which one was recognized both as a Christian and a member of a Hindu-defined high status group. At the same time, it enabled them to emphasize religion over stigmatised disease status, particularly if the latter threatened to undermine caste position in the eyes of society beyond the community. Wearing their Christianity lightly, as it were, also allowed for its temporary suspension during return visits to their natal, Hindu - or occasionally Muslim - communities, offering ways of reconciling apparently opposed identities.

For those of lower status, on the other hand, conversion allowed a renegotiation of status. They rejected the negative associations of their caste ascriptions and defined themselves as the most devout - and therefore at the top of one of the community's hierarchies - of all Christians within the village, worthy of respect precisely because of the differences between them and the 'regular Christians' who were less overtly devout.

Christianity in India is - and, as the historical record shows, always has been flexible, multiple and changing. Conversion to it, likewise, is more complex than an instrumental, materialist analysis can account for, and it is for the reason, I suggest, that biographies of converts - particularly when they are ethnographically contextualized can be so revealing of how religious affiliation is lived, and how it might change across the life course in relation to other social changes. 